\title{
Technology and the Library
}

\begin{abstract}
Technology has dramatically changed our environment and life-style, and more specifically information technology plays a role both in library administration and in use of information resources. Viewed in historical perspective, the "computer era" is just beginning, and the prospect of the "electronic book" is good. Librarians must be computer-literate and lead students and the public in the use of new information technologies.
\end{abstract}

As the most technologically advanced great nation in the late twentieth century we are a center from which radiate the forces that unify human experience. Ideology, tribalism, nationalism, the crusading spirit in religion, bigotry, censorship, racism, persecution, immigration and emigration restriction, tariffs, and chauvinism do interpose barriers. But these are only temporary. The converging powers of technology will eventually triumph. They triumph for a host of reasons which we are only beginning to discover. ${ }^{1}$

I found this quotation an interesting introduction to a discussion on the role of technology and the library for two reasons. First, it comes from a distinguished historian, not a scientist. Second, it states a ringing challenge for every person engaged in the information sciences. It comes from the foreword to a new book, The Republic of Technology, by Daniel Boorstin, Librarian of Congress.

I want to use this occasion to briefly explore the hypothesis that technology, more specifically information technology, will have a more far-reaching effect on our society and other societies of the world than we can now imagine. I want you to consider the proposition that as professional librarians, one of the premier professions in the information field, you stand at the entrance to a gateway of opportunity that few professionals have ever experienced. In the vernacular of the current White House, you have the opportunity to be "born again."

Joe B. Wyatt is vice-president for administration, Harvard University, Cambridge, Massachusetts.
I should warn you that the opportunity includes the obligation of an intellectual change not unlike the move from the sheltered womb to the rigors and demands of the earthly environment. But opportunity as exciting and rewarding as you have before you usually carries the price of change.

\section{TeChNOLOGY IN OUR Lives}

Technology has played a major role in the lives of Americans for several decades, and it continually dramatically changes our environment and our life-style. Permit me to characterize this personally in a brief anecdote.

I am professionally engaged as a teacher, researcher, and practitioner of computer science and technology. But I was born and raised on a small farm in Texas. When I was a youngster, we heated the house and cooked with wood that we cut and split. We had no electrical power. We had no telephone. We had no running water. As time passed, we got electrical power and the benefits of the electric light. It was a long time before I had to stop drawing water out of the well. We didn't get a telephone until I was a teenager. In other words, technology was minimal in my beginnings, and I do know how it feels to move "from the land to the machine." 2 (I may be one of the only computer scientists in the world who can harness and plow a mule.)

This anecdote is clearly personal, but it characterizes the kind of change that my generation is experiencing. I think it important that you consider for a moment those changes that technology has brought to your 
own lives. Many people have viewed changes wrought by technology very negatively. Henry David Thoreau said in the late nineteenth century that "men have become the tools of their tools." But even Thoreau, whose writings lashed out at technology and societal change, had a personal attitude toward technology that differed from his oft-recorded view. First, he was an accomplished land surveyor and, as such, was a practitioner of technology. His surveying instruments can still be viewed at the Antiquarian Museum in Concord, Massachusetts. Second, I am told on the best of authority that Thoreau, while ostensibly at Walden, occasionally sneaked back through the woods after dark to the Emerson house for some high-technology cooking!

\section{FUTURE EFFECTS OF Technological Change}

As you may have already guessed, I view the prospects of technological change with great enthusiasm and hope. I do not long to return to a world in which there are no electrical power, no convenient water supply, and no telephone-not to mention the other conveniences offered by technology that free us for intellectual activity. I look forward to the contribution that technology can make to overcome societal problems in the future.

For this discussion I would like to couch my enthusiasm in terms of the opportunities represented by information technology. I have spent a professional career in the field. I think that technology represents a great opportunity for those engaged in the information professions such as yourselves. My discussion of the role of technology in the library will be divided into two parts. The first part concerns the use of technology in the administration of libraries. The second part concerns the effect of information technology on the resources that will be a part of the library collection. After a brief visit to the first area, I will dwell on the second.

\section{TECHNOLOGY IN LIBRARY ADMINISTRATION}

The use of computer and communications technology in library administration has re- ceived substantial attention over the last two decades. Their effect on one of the largest and most difficult of the administrative tasks, that of cataloging the collection, has been attacked exhaustively in the last few years-one might even say exhaustingly. But much progress has been made. Several systems are in operation now, and they continue to be developed and refined. I am very enthusiastic about that problem's being licked, with all due respect to those who are continuing to work away on it. The major conceptual and technological barriers are now passed, and it is time for refinement of systems and standards.

\section{TECHNOLOGY AND THE LIBRARY'S INFORMATION ROLE}

So much for the brief visit to the issue of information technology and library administration. Now for the issue of information technology and the informational role of the library.

\section{The Perspective of Time}

First, consider the perspective of time. In the history of mankind there have been four great inventions relating to information communication. The first was writing, begun by the Egyptians and Accadians about five thousand years ago. Second was the development of an alphabet by the Greeks about three thousand years ago. The third was the invention of movable type by the Koreans about seven hundred years ago and developed independently by Gutenberg about five hundred years ago. The last of the great inventions is the stored program computer conceived by John Von Neumann about thirty years ago.

Think for a moment about the time line that these four great inventions represent. It was two thousand years between the invention of writing and the alphabet. About two thousand years elapsed between the developments of the alphabet and movable type. And five hundred years passed between the invention of movable type and the computer. But only thirty years have elapsed between the invention of the computer and today. Although the changes wrought in those thirty years are mindstretching, if one looks at the perspective of time, the "computer era" is just beginning. 
The thirty years are only a tiny fraction of any of the other historical intervals.

Early applications of the computer to information problems occurred in laboratory environments with objectives like calculating artillery tables and predicting the weather. (In the first case it was very successful, and in the second case it's making progress.) These computers were housed in large and expensively air-conditioned rooms. They were manifested in massive electronic and mechanical devices as late as 1955. And each one cost millions of dollars.

Yet today the power of these devices, even computers more powerful than those early computers in every way, can be held in my hand, carried in my pocket, and used wherever I go. Moreover, these devices that I can hold in my hand have brothers and sisters, through the genealogy of largescale integrated-circuit chips, that continually find expanded roles in almost every human endeavor, particularly in the communication and processing of information.

For example, I walked over to the Harvard Coop early this morning to see a new gadget called Speak and Spell (a registered trademark of Texas Instruments, Inc.). It is a little box that ostensibly helps to teach youngsters spelling. It has a typewriter keyboard and a "vocabulary" of two hundred words or so. (According to the salesman, it will soon have a vocabulary of several thousand words.) The vocabulary is interchangeable by a switch of small magnetic memories. Plans include a vocabulary of foreign languages. It is portable and battery operated and costs fifty dollars. At its heart is a voice synthesis chip, a key invention. It means that a small collection of LSI chips can take words spelled out in digital form, as from a computer, and convert them to high-quality audio output at a very low cost. To begin the process of getting your mind around where this little toy and its kin may be going, drop in to your local electronics store and take a look.

For those of you who haven't been there lately, your future holds a treat. You will find numerous examples of information technology that you can buy for your personal use at prices well under a thousand dollars, that only a few years ago were not available outside the laboratory and cost tens and hundreds of thousands of dollars. You may even begin to believe as I do that the "electronic book" is not just science fiction.

\section{The Information Industry}

Consider another perspective on the information issue. In 1860 over 40 percent of the work force in the United States were farmers, and under 20 percent worked in factories. By 1950, at the peak of what we have come to call the industrial society, over 40 percent of the work force had moved to the factories, and only 10 percent stayed on the farm. Today half of the work force in the United States are employed in what is called the information industry: processing, communicating, researching, developing, and administering information in one form or another.

Let me describe briefly an economic characterization of that information industry. In terms of a U.S. gross national product of 1,295 billion dollars in 1973, broadcast television accounted for 3.5 billion, cable television another 0.5 billion, radio 1.5 billion, newspapers 8.3 billion, books 4 billion, periodicals 3.7 billion, telephone 25.5 billion, postal service 8.3 billion. Computer software in 1973 was already at the level of 3.7 billion (not hardware, just software). And libraries accounted for 3.5 billion. When one adds in computer hardware, advertising, education, and other information enterprises, it comes to over 300 billion dollars. Banks, law firms, and a number of other "information businesses" would include a marketplace that approaches 500 billion dollars.

Every one of these segments of the information industry was growing then and is continuing to grow now. In this marketplace it is very clear that information distribution is becoming more decentralized and more personalized.

\section{Information Literacy and Information Growth}

The media are becoming more complex. Information literacy has become a problem along with information overload. As children some of us read everything we could get our hands on, but we couldn't get our hands on much to read. If a child of today tried to 
read or otherwise absorb all of the information that is available, it would be absolutely impossible. In today's society and even more in the future, it is a necessity to be both selectively literate and multitechnology literate to take advantage of available information resources.

Kas Kalba, who heads a consulting firm that specializes in the information technology field, recently gave a partial list of the kinds of literacy that one needs: computer literacy, CB radio literacy, newsletter literacy, graphic arts literacy, on-line retrieval literacy, legal literacy, consumer information literacy, pocket calculator literacy. ${ }^{3}$

Obviously, the list is not exhaustive in terms of the kinds and types of information that is not only available to us but is often thrust on us. I believe that if libraries are to remain active information resources then librarians must not only become multiliterate but must also bear a major responsibility for leading students and the public to multiliteracy in these new information technologies.

About a year ago Richard Atkinson, the director of the National Science Foundation, asked me to chair a multidisciplinary committee to review the National Science Foundation's programs on information science, science information, and the like. It was one of the most productive such efforts that I have ever experienced. I know those of you from universities are likely to be engaged in endless task forces. This one, of course, produced a report that was added to all those other reports that line the shelves. But our report was only nineteen pages in length. It recommends, among other things, that the National Science Foundation establish a new basic research program in information science and technology.

The recommendation is being followed. A new Division of Information Science and Technology has been established. Its new director, Howard Resnikoff, has begun work. I will paraphrase a statement of the information problem that he first mentioned as a member of the committee and has more recently refined. Resnikoff relates his perspective to the work of Thomas Robert Malthus, who, in 1798, wrote his Essay on Population relating to the growth of human and animal populations. ${ }^{4}$
Like people, information is a rapidly growing resource in contrast to almost every other resource on earth. That is, most other resources are diminishing and being used up. Information is not being used up; it is growing. Like people, information must be sheltered and cared for. But sheltering and caring for information in its traditional printed form consume other more scarce and diminishing resources. Moreover, it leads to a Malthusian struggle for existence, analogous to that which afflicts the human population. Darwinian evolution may even play a role in this struggle in that only the fittest information may survive.

Clearly, the population pressure of information will continue to test the capacity of society to contain it. Zero population growth for information is even less plausible than one can imagine for human zero population growth. So, as Resnikoff puts it, "we find ourselves between the hammer of information population pressure and the anvil of societal need for information." He goes on to say that "we do not yet know how to do what must be done." Therein lie both the problem and the opportunity to those engaged in the information professions.

I certainly don't know what the future might hold for our information society. It is almost reckless to predict. But one might imagine a world in which our present libraries become information museums, collections for retrospective research and historical significance-a world in which every home, perhaps each person, can be instrumented with information technology so as to communicate freely with the rest of the world.

I feel safe with only one prediction. Whatever the future does hold in the development of new information technology will, if we remain a free enterprise society, happen almost spontaneously just as it has in the last three decades. No bureaucracy is in control of the basic ingenuity and entrepreneurial spirit that characterize the development of new technology, thank God. And you are stakeholders. Virtually everything that you encounter as professional librarians is affected by this spontaneous and rapid change including the media, the economics, and the public policy of information technology. 


\section{THE LIBRARIAN'S RESPONSE}

In conclusion, I suppose that it is fair to suggest how you as librarians might deal both personally and as a profession with the issues that $I$ have raised. I have an idea. It falls into the category of a recycled idea rather than a new one. But it seems to work in its other contexts.

I have long been interested in academic programs to train practicing computer professionals for business and government, curricula that combine in-depth knowledge about computer technology with in-depth knowledge about business and government.

At Harvard we have established such a program jointly between the Division of Applied Science (in the Faculty of Arts and Sciences) and the Harvard Business School. We started admitting students four years ago in groups of eight. We were immediately oversubscribed. The experimental program was enormously successful, and it has now become a regular option in the M.B.A. program of the Harvard Business School. It currently engages about ninety students.

Also at Harvard, the John F. Kennedy School of Government has a professional program in public administration leading to the M.P.A. The program admits those who have practiced in the public administration area and who plan to return. I teach a course in the Kennedy School called Management Information Systems in Government that is a part of this program. The course is heavily subscribed. Case material on information technology and its use in government makes an important contribution.

For example, one of my cases concerns a computer-based information system in the United States Congress, the House of Representatives to be specific. Those of you who know the Library of Congress know that the House members often ask for information from the Library of Congress. You would probably safely predict that they will ask more and more and more. In addition, many members of the House have already instrumented their own offices with computer terminals or small computers. And more than one member now employs a computer programmer as legislative aide.
In dealing with information technology policy, these members of Congress are not only becoming familiar with the technology through the normal legislative information process but also through personal experience as users. So we can expect a more broadly informed legislative branch both making and questioning information technology policy.

I suggest that you review and reconsider your academic programs in library science, including mid-career programs. Demand enlightened curricula that include basic material from the information technologies. This includes computer-based system design, development, management, and use-their complete understanding.

Every librarian should be computerliterate - to be able to read and write computer programs for a variety of information applications. To avoid doing so will, over time, result in a growing lack of understanding for both the new material that you will find in your collection and the computerliterate clients who wish to use it. And to avoid doing so is to eventually become a follower and not a leader in our informationcentered society.

I will end this discussion, as I began it, with a quotation from Boorstin:

We must be willing to believe both that politics is the Art of the Possible and that technology is the Art of the Impossible. Never before has a people been so tempted (and with such good reason) to believe that anything is technologically possible. ${ }^{5}$

\section{REFERENCES}

1. Daniel Joseph Boorstin, The Republic of Technology: Reflections on Our Future Community (New York: Harper, 1978), p.xv.

2. Chapter 3 of Boorstin's book is titled "From the Land to the Machine."

3. Kas Kalba, "Libraries in the Information Marketplace," in Libraries in Post-Industrial Society (Phoenix, Ariz.: Oryx Press, 1977).

4. Howard L. Resnikoff, "Remarks on a National Information Policy," presented at the Conference on Federal Support of Library and Information Services sponsored by the National Commission on Libraries and Information Science, September 1978.

5. Boorstin, The Republic of Technology, p.34. Italics in original. 